\title{
GIS-based environmental risk assessment in the Ribeira Valley, São Paulo, Brazil
}

\author{
José Maria Filippini-Alba · Carlos Roberto de Souza Filho
}

Received: 27 October 2008/ Accepted: 10 February 2009/Published online: 4 March 2009

(C) Springer-Verlag 2009

\begin{abstract}
The Ribeira Valley region (State of Sao Paulo, Brazil) hosts the largest Brazilian Atlantic forest reserve. The region was an important mineral district during the ' 60 s, from where several tons of lead and other metals were exploited. Residual materials produced by the mining are diffused in the environment until today. The area also encompasses a regional arsenium anomaly associated with unexplored gold deposits. The population presently living in this region performs basic farming activities, from which most of their food is yielded. These features coupled together imply in a complex relationship between natural and anthropogenic factors that are likely to affect the life and health of the local communities. The aim of this paper is to apply digital data integration techniques for environmental risk assessment in the Ribeira Valley using environmental geochemistry. Geochemical, digital elevation and remote sensing data (Landsat Thematic Mapper) were merged and analyzed using a geographical information system. The assumed model considered environmental mobilization through erosion and anomalous $\mathrm{As}-\mathrm{Pb}$ areas. Data were analyzed through Boolean and fuzzy logic techniques. Fuzzy logic proved superior in this case study as it allowed not only the detection but also the distinction between low, moderate and high environmental risk areas.
\end{abstract}

\footnotetext{
J. M. Filippini-Alba ( $ه)$

Brazilian Agricultural Research Corporation,

Center for Temperate Climate Agricultural Research,

Post Box 403, Pelotas,

Rio Grande do Sul 96001-970, Brazil

e-mail: fili@cpact.embrapa.br

C. R. de Souza Filho

Department of Geology and Natural Resources, Institute of Geosciences, State University of Campinas, Post Box 6152, Campinas, Sao Paulo 13083-970, Brazil
}

Keywords Risk assessment · GIS · Geochemistry

\section{Introduction}

The Ribeira Valley was an important lead producing region of Brazil during the '60s. Moraes (1997) reported the mining of some 2.4 million tons of ore during this period, with an average of $7 \%$ in lead, and a total equivalent of 165,000 tons of metal. The principal mines were located at Upper Ribeira Valley. In the Middle Ribeira Valley, between the cities of Iporanga and Eldorado (Fig. 1), there are several occurrences of gold and massive sulfides related to Mesoproterozoic Formations, where a regional geochemical anomaly of As was defined (unpublished data by Addas and Vinhas 1975; Morgental et al. 1975, 1978). In contrast, the Ribeira Valley comprises numerous environmental protection areas and it hosts the largest Brazilian reserve of Atlantic forest. Farming is the dominant human activity in the area, for which socioeconomical parameters show evidences of underdevelopment (Hogan et al. 2000). These features represent a particular situation, because of the interplay between anthropological processes $(\mathrm{Pb}$ mining; farming), natural geological process (As regional anomaly) and environmental protection areas. Actually, both trace elements are related to global health problems (Tong et al. 2000; $\mathrm{Ng}$ et al. 2003).

For this reason, several studies were developed in the region, involving environmental geochemistry (Silva 1997; Moraes 1997; Toujague 1999) and medical geology (Paoliello 2002; Cunha 2003; Sakuma 2004).

Geographic information systems (GIS) have been widely applied in Geosciences (Bonham-Carter 1994) during the last 20 years. Logistic models in mineral exploration showed promising results (Bonham-Carter 
Fig. 1 Location of the study area and stations of geochemical stream sediment samples. $P R$ Parana State (gray), SP Sao Paulo State (white), B Barra do Turvo village, $F$ Furnas mine, $I$ Iporanga village

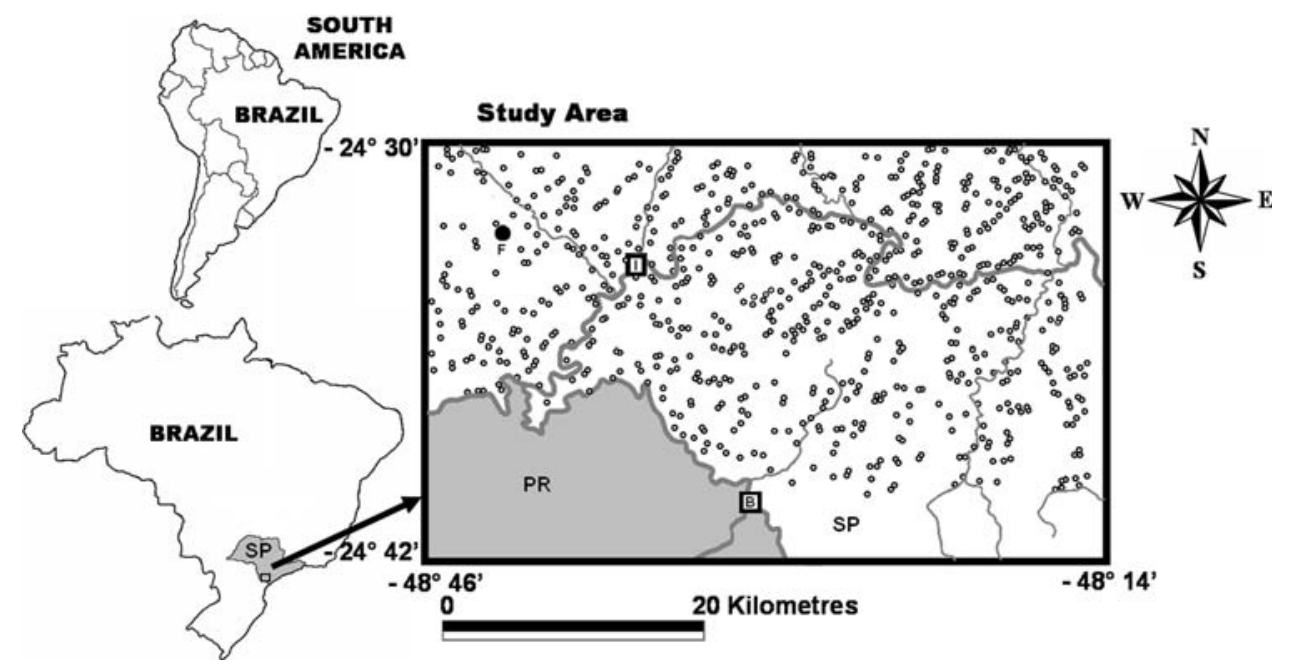

et al. 1988; Harris 1989; Barros-Silva 1992; Kuosmanen et al. 1988; Tiainen and Viita 1994; Filippini-Alba 1998). Perrotta (1996) and Moura (1997) proved the usefulness of GIS techniques and spatial models in locating sites with potential for gold in the Middle Ribeira Valley.

Data fusion derived from GIS analysis is extremely important for environmental evaluation and risk assessment. In this study, multi-element geochemical data, digital elevation models and remote sensing data were employed to characterize sectors in the Middle Ribeira Valley, where erosive processes and geochemical anomalies of $\mathrm{As}$ and $\mathrm{Pb}$ occur simultaneously, using a GIS-based environmental risk analysis. These sectors represent a potential risk for individuals living in the area, from the point of view of chronic toxicology.

According to the methodology proposed by Covello and Merkhofer (1993) this paper is mainly related to release assessment. The term "contamination" is used here in a broader sense, independent of natural or anthropogenic causes associated to it.

\section{Study area}

The study area is located at the southeastern portion of the Sao Paulo State, southern Brazil, at about $150 \mathrm{~km}$ from the Sao Paulo city (Fig. 1). The region is mountainous, karstic and humid, with large areas of Atlantic forest. Farming (banana and black tea plantations; cattle) and extractive activities are dominant. Socio-economical parameters show evidences of underdevelopment (Hogan et al. 2000).

Geologically, the area comprises NE-SW-trending supracrustal sequences, including clastic, chemical and clastic-chemical metasedimentary rocks intercalated with basic metavolcanic rocks of the Acungui Group (Perrotta 1996). These metasedimentary sequences are cut by synorogenic and late-orogenic granitoids of unknown age.
Mesozoic, mafic dyke swarms and alkaline intrusions occur in the area.

A regional geochemical anomaly of As based on stream sediments and soil geochemistry was revealed in this area by Perrotta (1996). This anomaly is related to a lithological unit mineralized with $\mathrm{Au}$, coined as the Piririca unit (Perrotta and Campos-Neto 1999). This unit comprises a metavolcanic-sedimentary sequence formed by deep-water carbonaceous phyllites, shallow-water carbonate-bearing phyllites and basaltic volcanic rocks.

An important $\mathrm{Ag}-\mathrm{Pb}$ mine named Furnas is located at the northwestern sector of the study area (Fig. 1). According to Moraes (1997), epigenetic lodes intersect the host rocks discordantly. Mineralization is structural-controlled and composed mainly of galena, sphalerite and pyrite. Mesoproterozoic carbonaceous and carbonated phyllites are the main host rocks. Radiometric $\mathrm{Pb}-\mathrm{Pb}$ dating in galena indicated an age of 1.1-1.4 Ga for the mineralization (Moraes 1997 and references therein).

\section{Materials and data processing}

The geochemical data presented in this paper were retrieved from reports produced during an exploration survey in the Ribeira Valley (unpublished data, Institute of Research Technology of São Paulo State 1985). Stream sediment samples were collected according to an irregular grid (Fig. 1) and analyzed for 24 elements using a $<80$ mesh fraction. Optical emission spectrometry was used for determination of $\mathrm{Ca}, \mathrm{Fe}, \mathrm{Mg}, \mathrm{Mn}, \mathrm{Ti}, \mathrm{B}, \mathrm{Ba}, \mathrm{Be}$, $\mathrm{Co}, \mathrm{Cr}, \mathrm{Cu}, \mathrm{La}, \mathrm{Li}, \mathrm{Mo}, \mathrm{Nb}, \mathrm{Ni}, \mathrm{Pb}, \mathrm{Sn}, \mathrm{Sr}, \mathrm{V}, \mathrm{Zn}$ and $\mathrm{Zr}$; atomic absorption spectrometry for As and specific ion electrode for $\mathrm{F}$.

Considering their particular spatial signature and relevance for environmental analysis, metals such as Fe, Mn, As, $\mathrm{Co}, \mathrm{Cr}, \mathrm{Cu}, \mathrm{Ni}, \mathrm{Pb}, \mathrm{V}$ and $\mathrm{Zn}$ were here approached. 
Geochemical maps of $\mathrm{As}$ and $\mathrm{Pb}$ were produced through interpolation using the inverse of square distance method available in the ArcGIS software (ESRI 2008) with pixel of $200 \mathrm{~m}$, reach ratio of $2,500 \mathrm{~m}$ and cutting value of eight samples. These maps were classified on the basis of numerical sediment quality assessment guidelines (USEPA 1999). Stream sediments were assigned as innocuous, low or highly contaminated on the basis of their As- $\mathrm{Pb}$ content and maps were produced to represent the spatial distribution of environmental risk. Studies of $\mathrm{As}$ and $\mathrm{Pb}$ migration in Ribiera Valley oriented that process (Filippini-Alba et al. 2003; Filippini-Alba and Souza Filho 2007).

The map of bare soils was yielded from processing and interpretation of Landsat-7 Enhanced Thematic Mapper plus (ETM+) data, bands 1, 2, 3, 4, 5 and 7, acquired on 26 September 1999. The data were classified through unsupervised procedures, using the ISODATA algorithm (e.g., Tou and Gonzales 1974). Twenty classes were yielded in the process. Classes of bare soil, vegetation and water were derived as a function of DN means evenly distributed in the six-dimensional ETM+ data space; the remaining pixels were clustered using the minimum distance technique. A binary map of the distribution of bare soils and vegetation in the study area was produced and stored as a categorical evidential map.

Slope information was obtained from digital elevation models derived from Shuttle Radar Topography Mission (SRTM) data (USGS 2003) using ArcGIS tools (ESRI 2008). All data were registered at Universal Transector of Mercaptor projection, zone 22, datum Corrego Alegre.

\section{Methodology}

Bare soil and slope maps and geochemical maps of As and $\mathrm{Pb}$ content in stream sediments were resample for pixel of $200 \mathrm{~m}$ and integrated through GIS techniques, using both Boolean and fuzzy logic operators (Bonham-Carter 1994).

Sectors of bare soils with higher slope are more sensitive to erosion processes than sectors with vegetation and lower slope. Thus, geochemical migration will be greater in sectors of bare soils with higher slope and the potential risk for environment or public health will be associated to potentially harmful contents of metals such as $\mathrm{As}$ or $\mathrm{Pb}$. Therefore, a highly environmentally risky condition will exist in areas where "bare soil + high slope $+\mathrm{As}$ and $\mathrm{Pb}$ greater than the guideline" spatially coincide.

Boolean logic uses binary maps, where each pixel has only two possible values, either 0 or 1 (Bonham-Carter 1994). When the slope map is considered, the " 0 " value means "low slope or slope lower than or equal to $20^{\circ}$ " and the value "1" means "high slope or slope greater than $20^{\circ}$ ". For the As map, the "0" value means "As content lower than guideline" and " 1 " means "As content greater than guideline". In contrast, fuzzy logic uses several classes for each map, where each pixel has value " $x$ " varying between 0 and $1(0 \leq x \leq 1)$. Fuzzy sets are graduated in the sense that membership in a fuzzy set is a matter of degree (Zadeh 1965).

Four binary maps were employed for spatial data integration using Boolean logic and the criteria presented in Table 1. Spatial analysis was obtained with AND - OR operators, such as (bare soil map) AND (slope map) AND [(As map) OR ( $\mathrm{Pb}$ map)].

The strategy used for the fuzzy logic modeling is showed in Table 2. The fuzzy membership for each class was defined in the range $[0,1]$, allowing for gradational membership. The membership for the categorical data (bare soil map) was attributed manually. The membership for As and $\mathrm{Pb}$ (ordered data) was assigned using USEPA guidelines and statistical parameters. The membership for slope data (ordered data) followed an equal interval rule. Fuzzy spatial data analysis was performed using a combination of Fuzzy-Or and Fuzzy-Product operators (BonhamCarter 1994), as follows: Fuzzy-Product [Fuzzy(bare soil map) $\times$ Fuzzy(slope map) $\times($ Fuzzy-Or (Fuzzy(As map) + Fuzzy(Pb map))]. This combination produced an "index" that proved suitable for mapping risky sectors.

The fuzzy risk threshold was set to 0.45 . This threshold comprises a combination of (1) bare soil, (2) slopes within $13^{\circ}-17^{\circ}$, (3) As content within 35-70 ppm and, (4) $\mathrm{Pb}$

Table 1 Description of variables related to Boolean logic

\begin{tabular}{lllll}
\hline BV & Soil map & Slope map & As map (ppm) & Pb map (ppm) \\
\hline 0 & Vegetation cover & $\leq 20^{\circ}$ & $\leq 85$ & $\leq 100$ \\
1 & Bare soil & $>20^{\circ}$ & $>85$ & $>100$ \\
\hline
\end{tabular}

$B V$ binary value

Table 2 Classification criteria for the fuzzy logic model

\begin{tabular}{|c|c|c|c|c|c|c|c|}
\hline \multicolumn{2}{|c|}{ Bare soil map } & \multicolumn{2}{|c|}{ Slope map } & \multicolumn{2}{|c|}{ As map } & \multicolumn{2}{|l|}{$\mathrm{Pb}$ map } \\
\hline Class & FV & Class & FV & $\begin{array}{l}\text { Class } \\
\text { (ppm) }\end{array}$ & FV & $\begin{array}{l}\text { Class } \\
\text { (ppm) }\end{array}$ & FV \\
\hline Vegetation & 0 & $0^{\circ}-4^{\circ}$ & 0.0 & $0-10$ & 0.0 & $0-45$ & 0.0 \\
\hline \multirow[t]{9}{*}{ Bare soil } & 1 & $4^{\circ}-9^{\circ}$ & 0.1 & $10-20$ & 0.2 & $45-90$ & 0.1 \\
\hline & & $9^{\circ}-13^{\circ}$ & 0.2 & $20-35$ & 0.4 & $90-130$ & 0.2 \\
\hline & & $13^{\circ}-17^{\circ}$ & 0.4 & $35-70$ & 0.7 & $130-220$ & 0.6 \\
\hline & & $17^{\circ}-22^{\circ}$ & 0.5 & $>70$ & 1.0 & $>220$ & 1.0 \\
\hline & & $22^{\circ}-26^{\circ}$ & 0.6 & & & & \\
\hline & & $26^{\circ}-30^{\circ}$ & 0.7 & & & & \\
\hline & & $30^{\circ}-35^{\circ}$ & 0.8 & & & & \\
\hline & & $35^{\circ}-39^{\circ}$ & 0.9 & & & & \\
\hline & & $39^{\circ}-43^{\circ}$ & 1.0 & & & & \\
\hline
\end{tabular}

$F V$ fuzzy value 
content within 90-130 ppm. Sectors mapped with fuzzy values smaller than 0.45 are considered risk-free, whereas those mapped with fuzzy values higher than the threshold indicate that at least one of these two potentially harmful elements exceeded the consensus value. For example, sectors with As content within 20-35 ppm and $\mathrm{Pb}$ within 90-130 ppm are only mapped as risky sectors in portions free of vegetation and where the slope is $\geq 35^{\circ}$.

\section{Results and discussion}

Geochemical signature

Basic statistics of $\mathrm{As}, \mathrm{Co}, \mathrm{Cr}, \mathrm{Cu}, \mathrm{Ni}, \mathrm{Pb}, \mathrm{V}$ and $\mathrm{Zn}$ contents are presented in Table 3. The histograms of some elements show several modes, suggesting the occurrence of many subpopulations that could be related to either lithological, mineralization or superficial phenomena.

Correlations for $\mathrm{Fe}, \mathrm{Mn}, \mathrm{As}, \mathrm{Co}, \mathrm{Cr}, \mathrm{Cu}, \mathrm{Ni}, \mathrm{Pb}, \mathrm{V}$ and $\mathrm{Zn}$ were analyzed through scatterplots. Fe presented relatively linear patterns against most elements, but $\mathrm{As}$ and $\mathrm{Pb}$. Scatterplots of $\mathrm{Mn}-\mathrm{Co}, \mathrm{Cr}-\mathrm{Cu}, \mathrm{Co}-\mathrm{Ni}, \mathrm{Co}-\mathrm{V}, \mathrm{Cr}-\mathrm{Ni}$, $\mathrm{Cu}-\mathrm{Ni}, \mathrm{Cu}-\mathrm{V}$ and $\mathrm{Ni}-\mathrm{V}$ also displayed linear patterns. Data analysis suggests the retention of trace elements by $\mathrm{Fe}-\mathrm{Mn}$-bearing superficial minerals or some inherit association related to mafic rocks ( $\mathrm{Fe}-\mathrm{Mn}-\mathrm{Co}-\mathrm{Cr}-\mathrm{Ni}-\mathrm{V}$ association). Scatterplots that include $\mathrm{As}$ or $\mathrm{Pb}$ showed dispersed patterns, also indicating the occurrence of several subpopulations.

Comparison of guidelines (USEPA 1999) and statistical data of potentially harmful elements yielded from 736

Table 3 Comparison of statistics of potentially harmful elements yielded from 736 samples of stream sediments (unpublished data, Institute of Research Technology of São Paulo State 1985) and USEPA guidelines

\begin{tabular}{lcccc}
\hline Element & Median & Percentile $80 \%$ & Maximum & ERL-ERM \\
\hline Fe (\%) & 4.1 & 6.3 & 11 & \\
Mn (ppm) & 1,300 & 3,000 & $>5,000$ & \\
As (ppm) & 11 & 29 & 550 & $8-70$ \\
Co (ppm) & 18 & 33 & 130 & \\
$\mathrm{Cr}(\mathrm{ppm})$ & 76 & 110 & 660 & $81-370$ \\
$\mathrm{Cu}(\mathrm{ppm})$ & 35 & 65 & 320 & $34-270$ \\
$\mathrm{Ni}(\mathrm{ppm})$ & 32 & 47 & 180 & $21-52$ \\
$\mathrm{~Pb}(\mathrm{ppm})$ & 26 & 44 & 2,500 & $47-218$ \\
$\mathrm{~V}(\mathrm{ppm})$ & 97 & 130 & 600 & \\
$\mathrm{Zn}(\mathrm{ppm})$ & 81 & 121 & 990 & $150-410$ \\
\hline
\end{tabular}

This work; unpublished data from Institute of Research Technology of São Paulo State 1985 (USEPA 1999)

$E R L$ effects range-low, ERM effects range-median comprise bioassays with adverse effects for 10 and $50 \%$ of the population, respectively (USEPA 1999) samples of stream sediments collected in the area (Table 3), shows that at least one guideline is exceeded for each element. This suggests sediment contamination by several elements. The As- $\mathrm{Pb}$ association is related to the sulfide mineralization and the $\mathrm{Cr}-\mathrm{Ni}$ association is related to mafic rocks found throughout the area. Only the former two elements were here considered for data integration.

Two regional anomalies were identified in the surface map of As content (Fig. 2). One is located in the NW portion of the area and related to the Furnas $\mathrm{Pb}$-mine; the other concurs to the NE-trending Piririca Unit in the central part of the area. The $\mathrm{Pb}$ surface map shows a similar pattern (Fig. 3).

\section{Data integration}

Figure 4 shows the distribution of bare soils sectors in dark gray and Fig. 5 shows the slope classified according to five intervals in gray levels.

Three main critical areas, named sectors A, B and C, where defined by Boolean approach and in similar way by fuzzy logic (Fig. 6). Figures 7, 8 and 9 display the detailed spatial variation of the risky areas (Fuzzy logic) in each of these sectors and a variation between lower and higher risky tracts.

Sediment quality guidelines are yet not issues embraced by federal laws in Brazil, but some particular States have adopted international guidelines for soils, such as the USEPA guidelines (Casarini et al. 2001). Although these guidelines were applied to the study area, possible bias should exist given the differences in climate and weathering conditions found in the Ribeira Valley in relation to higher latitude regions, for which the guidelines were conceived.

The spatial correlation between soil and stream sediments geochemistry is a complex topic. One of the key questions on the subject is: "What distance does exist between a geochemical anomaly in soil and the corresponding anomaly in stream sediments?" Published data by Govett (1983) and Kuosmanen et al. (1988) suggested a kilometric value for that distance. If soil geochemistry would be available and employed in the model proposed here, the geochemical anomalies could possibly appear somehow displaced. Filippini-Alba et al. (2008) mentioned overlapping between geochemical anomalies in sediments and soils in Riveira Valley, with restrictions for anomalies in soils of low contrast.

Risky sectors mapped both through Boolean and fuzzy analysis were rather similar as regards their spatial distribution into three main sectors, A, B and C (Figs. 8, 9). Besides these shared indications, fuzzy analysis highlighted another less significant risky sector in the southeastern portion of the area. 
Fig. 2 Map of As content in stream sediments interpolated through inverse of square distance (search radius $=$ 2,500 m). A Landsat-7 $\mathrm{ETM}+$ image (band 3) is shown in the background. The dashed polygon encompasses the Piririca anomaly

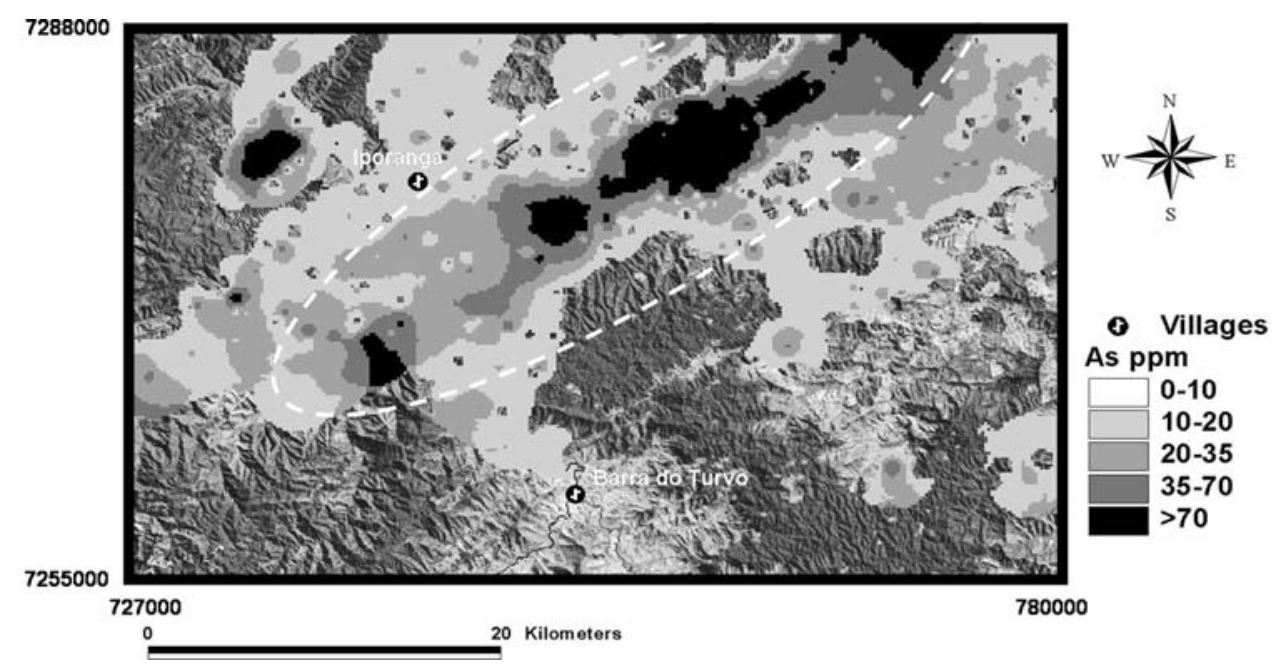

Fig. 3 Map of $\mathrm{Pb}$ content in stream sediments interpolated through inverse of square distance (search radius $=$ $2,500 \mathrm{~m})$. A Landsat-7 $\mathrm{ETM}+$ image (band 3) is shown in the background. The dashed polygon encompasses the Piririca anomaly

Fig. 4 Bare soil map
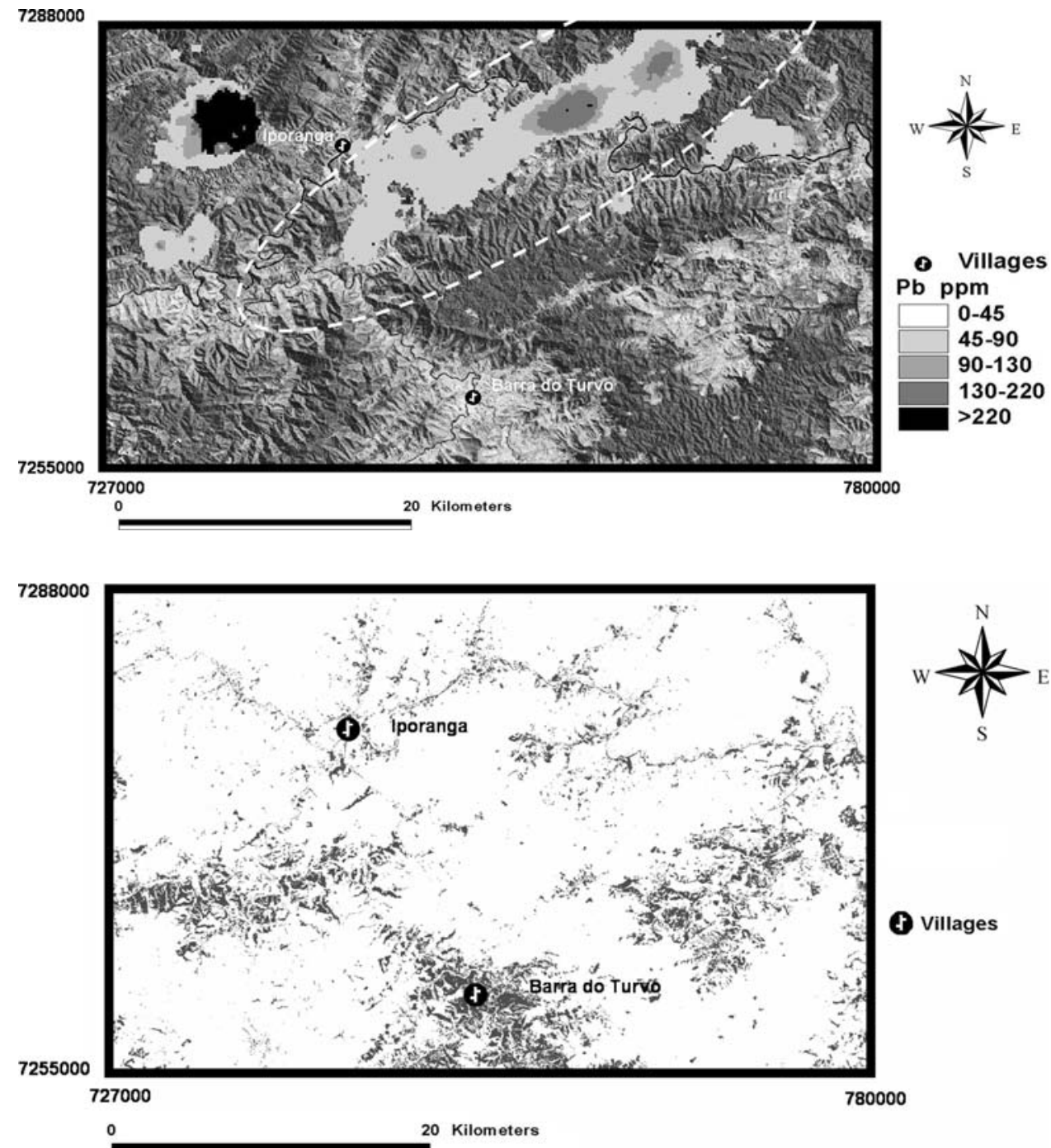

The advantage of fuzzy relative to Boolean logic derive from the fact that fuzzy values range from 0 to 1 , thus indicating areas with no risk and low, moderate and high risk, inside each main sector (Figs. 7, 8, 9). Sector A hosts higher fuzzy values than the other sectors, including values above 1.35 (i.e., three times higher than the threshold and 
Fig. 5 Slope map displayed in gray levels

Fig. 6 Risky sectors defined by fuzzy logic based on the fuzzy index $=$ fuzzy-product [fuzzy(bare soil map) $\times$ fuzzy(slope map) $\times$ (fuzzy-or (fuzzy(As map) fuzzy(Pb map))]. Sectors $A, B$ and $C$ agree plausibility with sectors mapped with the Boolean logic

Fig. 7 Risky areas (pixels) defined by fuzzy logic in sector A. A Landsat-7 ETM + image (band 3 ) is shown in the background
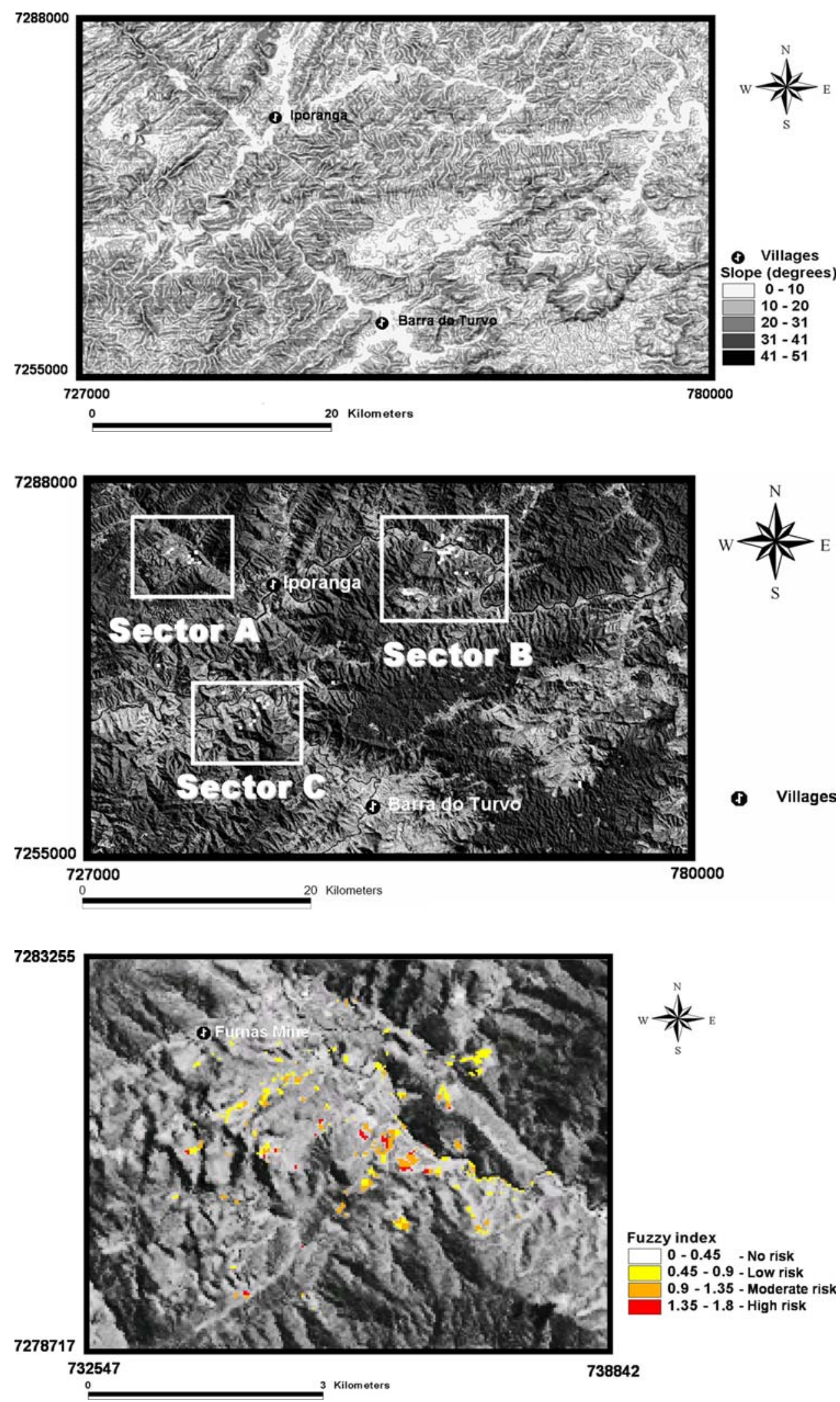

comprising slopes $>26^{\circ}$, As $>35 \mathrm{ppm}$ and $\mathrm{Pb}>130 \mathrm{ppm}$ ), whereas the majority of risky areas mapped in sectors $\mathrm{B}$ and $\mathrm{C}$ are mostly within $0.45-0.90$ fuzzy values. Sector A comprises $0.305,0.219$ and $0.045 \mathrm{~km}^{2}$ of low, moderate and high-risk areas, respectively (Fig. 7). Sector B hosts a total of $1.23 \mathrm{~km}^{2}$ of low risk areas and $0.067 \mathrm{~km}^{2}$ of 
Fig. 8 Risky areas (pixels) defined by fuzzy logic in sector B. A Landsat-7 ETM + image (band 3) is shown in the background. The dashed lines indicate the Piririca anomaly
Fig. 9 Risky areas (pixels) defined by fuzzy logic in sector C. A Landsat-7 ETM + image (band 3) is shown in the background. The dashed lines indicate the Piririca anomaly
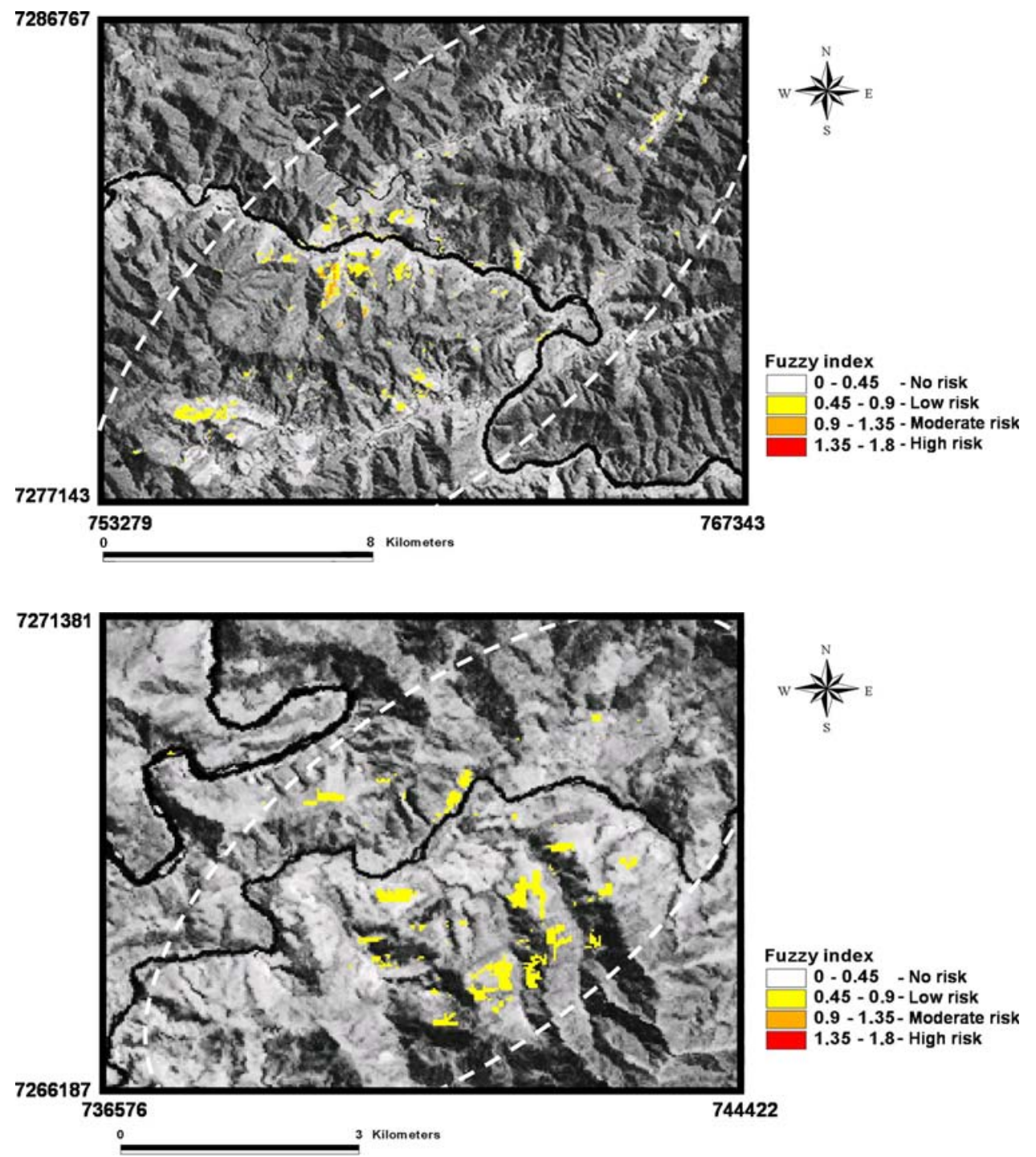

moderate risky areas (Fig. 8). Sector C shows only low risky areas that are distributed in a total of $0.81 \mathrm{~km}^{2}$ (Fig. 9).

The discrepancy found in the results for sector A and sectors $\mathrm{B}$ and $\mathrm{C}$ has a plausible explanation. Risky areas mapped within sectors $\mathrm{B}$ and $\mathrm{C}$ are related to the regional Piririca As-anomaly. This means that the environmental risk observed as low to moderate at these two sectors stems mostly from natural processes of erosion and dispersion of metals. In contrast, Sector A comprises places rich in polimetallic ore over which intense $\mathrm{Pb}$ mining activities took place almost uninterruptedly during some 20 years (e.g., Furnas mine), starting in the '60s. This sector shows intense anomalies of $\mathrm{Pb}$ and is mapped as a higher risky sector. This suggests that the observed risk in sector A is associated with a unique combination of natural and human processes that triggered an ubiquitous dispersion of abundant, toxic chemical elements in this area.
Korre et al. (2002) used a risk assessment strategy in Lavrio, Greece, where high lead loads occur in soils. The lead concentration in soils was mapped through GIS and geostatistics procedures and the level of exposure was simulated with the method of Monte Carlo for children and adults, considering body weight, ingestion rate and exposure characteristics. The present study assumed a different model for risk assessment, when remote sensing and geochemical data were merged in GIS environment focusing the geochemical migration of toxic elements and environmental parameters (declivity and vegetation cover). Perhaps, both methods could be integrated, thus a holistic perspective would be reached involving all stages of risk assessment methodology of Covello and Merkhofer (1993).

Paoliello (2002) and Cunha (2003) found that soil and domestic fine dust were the principal contamination sources for $\mathrm{Pb}$ in the Iporanga village at the Ribeira Valley, where high levels of the metal appeared in blood samples 
taken from local inhabitants. Sakuma (2004) had similar results for As in citizens of the Barro do Turvo village, located within the area comprised in the Piririca anomaly. These observations agree plausibly with our results.

\section{Conclusions}

Release assessment of $\mathrm{As}$ and $\mathrm{Pb}$ anomalies in the Middle Ribeira Valley was here performed in a novel way, on the basis of stream sediment geochemical data and pedological parameters. Results derived from fuzzy logic showed that the highest risk conditions are found around the Furnas $\mathrm{Pb}$ mine. The Piririca unit is related to an extended natural anomaly of As and, considering our results, it is understood as of minor environmental risk. The effects of the Piririca As natural anomaly may change though, with the advent of increasing human activities within its limits.

Boolean and fuzzy logic produced similar risky maps. Fuzzy logic was advantageous as a classifier of risk assessment because of sector A, which comprises the Furnas $\mathrm{Pb}$ mine, hosts higher risk than sectors $\mathrm{B}$ and $\mathrm{C}$, which are comprised within the As-rich, Piririca Unit. The Iporanga village is near areas simultaneous rich in As and $\mathrm{Pb}$, whereas Barra do Turvo village is near the As anomaly. Such observations indicate a possible distinction between anthropological and natural geochemical patterns. Also, these different geochemical signatures found at both locations are in conformity with the unique anomalous metal content found in biological samples of local villagers, features that were recognized during recent studies related to medical geology in the region (Paoliello 2002; Cunha 2003; Sakuma 2004).

Acknowledgments This work was part of the postdoctorate research of the senior author, funded by FAPESP (Grant Nr. 02/ 13341-6). The authors are grateful to Monica M. Perrotta (Geological Survey of Brazil, CPRM) for providing useful geological data. Carlos R. Souza Filho thanks CNPq for the research grants. Suggestions by Asit Choudhuri and Fernanda Ogola greatly improved the manuscript.

\section{References}

Barros-Silva A (1992) Mineral exploration in Northeastern Brazil: a data fusion approach and a GIS strategy. In: Ninth thematic conference on remote sensing for exploration geology. Pasadena, Proceedings, pp 55-63

Bonham-Carter G (1994) Geographic information systems for geoscientists: modelling with GIS. Pergamon, Ottawa, 398 pp

Bonham-Carter G, Agterberg F, Wriqht D (1988) Integration of geological datasets for gold exploration in Nova Scotia. Photogramm Eng Remote Sens 54(11):1585-1592

Casarini D, Dias C, Lemos M (2001) Relatório de valores orientadores para solos e água subterrânea no Estado de São Paulo. CETESB, São Paulo, 73p
Covello VT, Merkhofer MW (1993) Risk assessment methodsapproaches for assessing health and environmental risks. Plenum Press, New York, $319 \mathrm{p}$

Cunha FG (2003) Contaminação Humana e Ambiental por Chumbo no Vale do Ribeira, nos Estados de São Paulo e Paraná, Brasil. $\mathrm{PhD}$ thesis, State University of Campinas, Campinas, $109 \mathrm{p}$

ESRI-Environmental Systems Research Incorporation (2008) ArcGIS 9.3

Filippini-Alba JM (1998) Análise e integração de dados geoquímicos e de sensoriamento remoto em um setor do cristalino Uruguaio. State University of São Paulo, São Paulo, 172 p

Filippini-Alba JM, Souza Filho CR (2007) Modelagem de As em prospecção geoquímica: estudo de caso no vale do Ribeira-SP. IN: Anais XIII Simpósio Brasileiro de Sensoriamento Remoto, Florianópolis, Brasil, 21-26 April 2007, INPE, pp 2239-2246. http://marte.dpi.inpe.br/col/dpi.inpe.br/sbsr@80/2006/11.01.20.08/ doc/2239-2246.pdf

Filippini-Alba JM, Souza Filho CR, Figueiredo BR (2003) Análise da Variância de dados geoquímicos assistida por Sistemas de Informação Geográfica: Estudo de caso no Vale do Ribeira. Geochim Bras 17(1):48-56. http://www.sbgq.org.br/arquivos/ art10004.pdf

Filippini-Alba JM, Souza Filho CR, Figueiredo BR (2008) Análise da assinatura geoquímica de solos e de sedimentos de corrente no Vale do Ribeira (SP) por meio de um sistema de informação geográfica. Rev Bras Geociências 38(1):68-79

Govett G (1983) Rock Geochemistry in mineral exploration, 1st edn. Elsevier, Amsterdam, $461 \mathrm{p}$

Harris J (1989) Data integration for gold exploration in Eastern Nova Scotia using GIS. In: Seventh Thematic conference on remote sensing for exploration geology. Calgary, Proceedings, pp 233-249

Hogan DJ, Carmo RL, Alves HPF, Rodrigues IA (2000) Sustentabilidade no Vale do Ribeira (São Paulo): conservação ambiental e melhoria das condições de vida da população. In: Migração e Ambiente em São Paulo. Aspectos Relevantes da Dinâmica Recente, vol 1. MPC Artes Gráficas, Campinas, pp 385-412

Korre A, Durucan S, Koutroumani A (2002) Quantitative-spatial assessment of the risk associated with high $\mathrm{Pb}$ loads in soils around Lavrio, Greece. Appl Geochem 17:1029-1045

Kuosmanen V, Arkimaa H, Gaál G, Huhtala T, Koistinen E, Lindqvist E, Murtoniemi S, Nikander J, Ruskeeniemi K, Salonen V, Talvitie J, Tennhola M, Tiainen M, Ward P (1988) Exploration target selection by integration of geodata using statistical and image processing techniques: an example from central Finland. Part 1 (Text). Geological Survey of Finland. Report of Investigation 80, Espoo, $156 \mathrm{p}$

Moraes RP (1997) Transporte de chumbo e metais associados no Rio Ribeira de Iguape, São Paulo, Brasil. Academic dissertation, State University of Campinas, Campinas, $94 \mathrm{p}$

Moura PA (1997) Potencialidade Mineral da porção média do Vale do Ribieira (SP) para Mineralizações Auríferas, obtida de um Sistema de Informação Geográfica-SIG. Master dissertation, State University of Campinas, Campinas, $110 \mathrm{p}$

Ng JC, Wang J, Shraim A (2003) A global health problem caused by arsenic from natural sources. Chemosphere 52:1353-1359

Paoliello MB (2002) Exposição humana ao chumbo em áreas de mineração, Vale do Ribeira, Brasil. PhD thesis, State University of Campinas, Campinas, $239 \mathrm{p}$

Perrotta M (1996) Potencial aurífero de uma região no Vale do Ribeira, São Paulo, estimado por modelagem de dados geológicos, geoquímicos, geofísicos e de sensores remotos num Sistema de Informações Geográficas. PhD thesis, State University of São Paulo, São Paulo, 150 p

Perrotta M, Campos-Neto MC (1999) Potencial aurífero no Vale do Ribeira estimado por meio de um Sistema de Informações Geográficas. Rev Bras Geociências 29(4):639-648 
Sakuma AM (2004) Avaliação da exposição humana ao arsênio no alto vale do Ribeira, Brasil. PhD thesis, State University of Campinas, Campinas, $161 \mathrm{p}$

Silva RH (1997) Geoquímica e impacto ambiental do Arsênio no Vale do Ribeira (SP-PR). Master dissertation, State University of Campinas, Campinas, $100 \mathrm{p}$

Tiainen M, Viita H (1994) Determination of ore potential areas in the Häme Belt, Southwestern Finland, by integration of geological, geophysical and till geochemical data. Geological Survey of Finland. Report of Investigation 125, Espoo, $49 \mathrm{p}$

Tong Sh, von Schirnding YE, Prapamontol T (2000) Environmental lead exposure: a public health problem of global dimensions. Bull World Health Organ 78(9):1068-1077
Tou JT, Gonzales RC (1974) Pattern recognition principles. AddisonWesley, London, $377 \mathrm{p}$

Toujague R (1999) Arsênio e metais associados na região aurífera do Piririca, Vale do Ribeira-SP, Brasil. Master dissertation, State University of Campinas, Campinas, $56 \mathrm{p}$

USEPA-US Environmental Protection Agency (1999) Environmental protection agency. Sediment Quality Guidelines developed for the National Status and Trends Program. http://www.epa. gov/waterscience/cs. Accessed in 16 October 2008

USGS-United States Geological Survey (2003) Shuttle Radar Topography Mission-SRTM. http://edc.usgs.gov/srtm/data/ obtainingdata.html. Accessed in 16 October 2008

Zadeh LA (1965) Fuzzy sets. Inf Control 8:338-353 